\title{
Analysis of the Improvement of Student's Geometry Achievement Through the Application of Problem-Based Learning Model in Term of Mathematics Prior Knowledge
}

\author{
$1^{\text {st }}$ Elita Zusti Jamaan \\ mathematics department \\ State University of Padang \\ Padang, Indonesia \\ elitajamaan_mat@fmipa.ac.id
}

\author{
$2^{\text {nd }}$ Diana Nomida \\ technology of education department \\ State University of Jakarta \\ Jakarta, Indonesia
}

\author{
$3^{\text {rd }}$ Zulfiarti Syahrial \\ technology of education department \\ State University of Jakarta \\ Jakarta, Indonesia
}

\begin{abstract}
Most students had the lack of understanding in learning geometry. The aims of this research are to obtain the influence of analysis problem-based learning in developing student's achievement of geometry and mathematics prior knowledge. The study design used a non-equivalent-controlgroup design. The instruments were test of mathematics prior knowledge and achievement of geometry. The data were analyzed quantitatively. The finding of this study was: there was a significant difference in the improvement of students' achievement of geometry and their mathematics prior knowledge.
\end{abstract}

\section{Keywords—problem-based learning, achievement of geometry test, mathematics prior knowledge.}

\section{INTRODUCTION}

Mathematics is one of subjects that play an important role both in the world of education and in everyday life. Regarding the importance of mathematics learning, the educators are required to be able to adjust and combine the appropriate learning model in mathematics learning [1]. From the results of pre-survey done in November and December 2017 in several junior high schools in Padang, it is obtained the information that the implementation of mathematics learning in class IX in some schools in Padang already uses the 2013 curriculum. This means that the teachers implement a scientific approach that is in accordance with the curriculum used at that time. This is also supported by the study of some journals that a scientific approach can improve students' mathematical competence. Another result of the survey is that the students have the lack of understanding in geometry learning, especially in understanding space and form, the properties of cubes, cuboids, prisms, and pyramids and their parts, as well as the nets of cubes, cuboids, prisms and pyramids. From the teacher training activities, the teachers state that they require the training in geometry with an average percentage of $48.1 \%$ [2]

Geometry occupies a special position in the mathematics curriculum, because it contains many mathematical concepts. From a mathematical point of view, geometry provides models for problem solving, such as: drawings, diagrams, and coordinate systems. In addition, geometry is one of mathematics's branches that foster logical thinking ability; development problem-solving skills and giving reasons. Therefore, a learning model that can improve student's learning outcomes and create a meaningful learning is required. Then, the teacher as a designer and manager of the learning should be able to think and plan a learning that is fun, easy, simple, and is able to encourage the students to think, understand problems and more activate them, so that they love mathematics even more.

One of solutions to solve this problem is problem-based learning model (PBL). Through PBL, students are invited to construct the knowledge by getting involved in solving problems. Students should solve problems by using their mathematics prior knowledge. While students engage in geometry-related tasks, they will engage in relationshipseeking activities, analyze patterns, find out which methods are appropriate and inappropriate, test the results, and rate and criticize their friends' thoughts. Activities undertaken in finding out the solution of geometry problems are expected to improve students' geometry learning outcomes.

PBL learning model requires student's activity optimally in understanding the concept and gaining the knowledge. PBL are both a curriculum and process of knowledge [3]. The process consisted of selected and designed problems which the learner acquisition of critical thinking, problem solving profit, directed learning strategies, and participation skills. The process replicated the commonly approach to resolving problems that are occurred in life and career [4]. Problem-oriented learning model such as problem-based learning is an effective learning to increase the potential possessed by the students. The problem situation presented in this learning is a stimulus that can encourage students' creative potential, especially in terms of problem solving [5].

The application of PBL model is expected to improve students' geometry learning result because "PBL is started from learning and working on problem situation given at the beginning of the learning with various difficulty level, ranging from easier to more difficult" [6]. So that, the students get the freedom to think and find out the solution of the given problems and construct by themselves the matter that are taught. Based on above description, PBL is which of alternatives to involve the students to become optimally 
active, enable them to investigate and improve their creativity and problem solving, which integrate thinking skills and understanding of concepts [7]. Therefore, the problem proposed in this research is "is there an improvement of geometry learning outcomes of the students that learn with PBL models viewed from their mathematics prior knowledge?"

\section{METHODS}

This study was conducted on the even semester of 2017/2018. The students of class IX SMPN 7 Padang are population. Two classes were chosen as the samples, namely: 1) class IX 7 consisting of 32 students labelled as a control class; 2) class IX 8 consisting of 30 students labelled as an experimental class. The sampling technique was done by using a purposive technique. The method used in this research design was non-equivalent group treatment. While the control class learned using a scientific approach, the experimental class learned using PBL. Additionally, the data was obtained from a test of geometry learning outcomes. The test used essay questions. Then, the data was normality and homogeneity. Based on the data analysis, it can be using t-test

\section{RESULTS AND DISCUSSIONS}

\section{A. The initial analysis of mathematics prior knowledge (PAM)}

The purpose of the PAM test was to know the equivalence of the research sample. To achieve this objective, the statistical analyses of PAM's score of the students were carried out. These statistical tests included normality test of data distribution, homogeneity test of variance, and the difference between two means of PAM's score of the students, between those who received learning PBL and who got PS learning.

Table I shows the average description and the standard deviation of PAM data based on the learning approach and the school level.

TABLE I. DESCRIPTION OF PAM DATA BASED ON LEARNING APPROACH

\begin{tabular}{|c|c|c|}
\hline \multirow{2}{*}{ Statistics } & \multicolumn{2}{|c|}{ Approach } \\
\cline { 2 - 3 } & $\begin{array}{c}\text { PBL } \\
\text { (Experiment) }\end{array}$ & PS (control) \\
\hline $\mathrm{N}$ & 30 & 32 \\
\hline Mean & 5,5 & 5,344 \\
\hline SB & 3,116 & 2,223 \\
\hline Max & 12 & 9 \\
\hline Min & 1 & 2 \\
\hline
\end{tabular}

To find out whether there was a significant difference between two means of PAM, then t-test was carried out. Before doing the t-test, the normality test of the data distribution and the homogeneity test of the population variance were done. Because PAM data was normally distributed and homogeneous, the t-test was used to test the equivalence of PAM. The results of t-test are shown in Table II.

TABLE II. THE RESULT OF SAMPLE EQUALITY TEST

\begin{tabular}{|c|c|c|c|c|}
\hline Class & T & Dk & Sig. & Ho \\
\hline IX & 0,23 & 60 & 0,82 & Accepted \\
\hline
\end{tabular}

Table II shows that of the t-test of PAM data with a significant value that is more than 0.05 . In the other words, all of the sample groups that were used did not have a significant difference in mathematics prior ability at a 0.05 significance level.

\section{B. Data analysis of the improvement of geometry learning outcomes}

1) Data analysis based on the learning model

The data of geometry learning outcomes test of the students was described and analyzed based on the learning model. This data was obtained from 62 people consisting of 30 students of experimental group (PBL) and 32 students of control group Using of the scientific method is a common component for increased literacy or the scientific approach. (PS) [8]. The data descriptions on the improvement of students' geometry learning outcomes including $\mathrm{N}$-gain average, and standard deviation (SB) N-gain based on the learning model were presented in Table III.

TABLE III. DATA DESCRIPTION OF GEOMETRY LEARNING OUTCOMES BASED ON THE LEARNING MODEL

\begin{tabular}{|c|c|c|l|c|c|c|}
\hline \multirow{2}{*}{ Statistics } & \multicolumn{6}{|c|}{ Approach } \\
\cline { 2 - 7 } & \multicolumn{5}{|c|}{ PBL } & \multicolumn{3}{c|}{ PS } \\
\cline { 2 - 7 } & PAM & HBG & $\begin{array}{l}\text { Mean } \\
\text { N-Gain }\end{array}$ & PAM & HBG & $\begin{array}{l}\text { Mean } \\
\text { N-Gain }\end{array}$ \\
\hline N & 30 & 30 & & 32 & 32 & \\
\hline Mean & 5.5 & 15.9 & 0.539 & $\begin{array}{c}5.34 \\
4\end{array}$ & 9.75 & 0.221 \\
\hline SB & 3.116 & 3.782 & 0.158 & 2.23 & 3.263 & 0.153 \\
\hline
\end{tabular}

Table III illustrates that the quality of geometry learning outcomes of the students who obtains the PBL learning model is greater than those who receive PS. This is indicated by the acquisition of mean score of $\mathrm{N}$-gain students from PBL group of 0.539 that is greater than the mean score from the PS group, which is only 0.221.

2) Data analysis based on the learning model and PAM

Table IV below presents a description of the $\mathrm{N}$-gain data of students' geometry learning outcomes from the learning model group and PAM.

TABLE IV. DATA DESCRIPTION OF GEOMETRY LEARNING OUTCOMES BASED ON THE LEARNING MODEL AND PAM

\begin{tabular}{|c|c|c|c|}
\hline $\begin{array}{c}\text { Learning } \\
\text { Model }\end{array}$ & $\mathbf{N}$ & Mean & SB \\
\hline PBL & 30 & 0.540 & 0.158 \\
\hline PS & 32 & 0.221 & 0.154 \\
\hline TOTAL & 62 & 0.761 & 0.312 \\
\hline
\end{tabular}

Table 4 illustrates that the quality of students' geometry learning outcomes based on the PAM group learning with PBL is greater than those who learn with a normal mathematical approach (PS). The mean difference of N-gain geometry learning outcomes taught through PBL and PS is 0.319 .

To know the presence or the absence of significant differences in geometry learning outcomes, the t-test was carried out. Before doing the t-test, firstly normality test of data distribution and homogeneity test of the population variance as a requirement were carried out. Table 5 below summarizes the results of the t-test. 
TABLE V. T-TEST RESULTS ON DIFFERENCES OF THE IMPROVEMENT GEOMETRY LEARNING OUTCOMES OF THE STUDENTS BETWEEN THE TWO APPROACHES

\begin{tabular}{|c|c|c|c|c|}
\hline Approach & $\begin{array}{c}\text { Mean } \\
\text { Difference }\end{array}$ & T & Sig. & Ho \\
\hline PBL*PS & $0.69: 0.58$ & 6.87 & 0.000 & Rejected \\
\hline
\end{tabular}

a. Ho : there is no difference in geometry learning outcomes between the approaches

Based on Table V, the value of Sig. is smaller than the significance level (0.05). We concluded that there were differences in geometry learning outcomes of the students between the learning used. In the other words, it can be concluded that there was the increasing of geometry result of the students learning by using PBL model.

\section{CONCLUSION}

The results of the research were an improvement on geometry learning outcomes of the students who learned with PBL model in terms of students' mathematics prior knowledge. There were two findings of this research, namely: (i) there was a significant difference in the improvement of students' achievement in geometry between learning processes applying problem based learning (PBL) and standard mathematical approach (PS); (ii) there was a significant difference in the improvement of students' achievement in geometry between learning processes using PBL and PS while being viewed from their mathematical prior knowledge.

\section{ACKNOWLEDGMENT}

We thank you our collegues from both Padang State of University and State University of Jakarta who facilitated and assisted this project.

\section{REFERENCES}

[1] A. Beliye, "Problem-Based Learning in Science Education", Journal of Turkish Science Education, vol. 6. 2009.

[2] Markaban. et al, Laporan Hasil Kegiatan Training Need Assessment (TNA) dan Rekruitmen Calon Peserta Diklat Guru Matematika SMP, Yogyakarta: PPPPTK Matematika, 2007.

[3] Stacy Rebich Spatial Thinking and Problem Based Learning, Center for Spatially Integrated Social ScienceUCSB Department of GeographyInstitute for Social, Behavioral, and Economic Research Santa BarbaraJuly 31 August 5, 2006

[4] Rebich. Stacy, "Spatial Thinking and Problem Based Learning", Center for Spatially Integrated Social Science UCSB Department of Geography Institute for Social, Behavioural and Economic Research Santa Barbara, 2006.

[5] Crowley. Brittany Marie, "The Effect of Problem-Based Learning on Mathematics Achievement of Elementary Students Across Time". Master Theses Specialist Projects Western Kentucky University, 2015.

[6] Etiubon, Rebecca and Authonia N Ugwu, "Problem-Based Learning and Students' Academic Achievement on Thermodinamics (A case of University of Uyo, Akwa-Ibom State, Nigeria)". (OSR-JRME) eISSN:2320-7388, P- Elissa, "Title of paper if known," unpublished, 2016.

[7] Wahyu, Erta Sri., Saliyar, Eva Marlina., and Qiutiug, "The Effect Of Problem-Based Learning Model toward Students' critical thinking and Problem Solving Ability in Senior High School". American Journal of Educational Research, vol. 5, pp. 633-638. DOI: 10.12691/ education 5-6-7, 2017.

[8] Guy R. McPherson, Teaching \& Learning the Scientific Method Guy R. McPherson The American Biology Teacher, vol. 63, APRIL 2001 